\title{
THE FLOW RATE OF THE FONTE PLINIANA (COMO, ITALY): TWO THOUSANDS YEARS OF DATA
}

\section{PRETOK KRAŠKEGA IZVIRA FONTE PLINIANA (COMO, ITALIJA): DVE TISOČLETJI PODATKOV}

\author{
Arrigo A. CIGNA ${ }^{1}$
}

\begin{abstract}
UDC 556.556(450.253)(091)

Arrigo A. Cigna: The flow rate of Fonte Pliniana (Como, Italy): two thousands years of data.

Since the Roman time the Fonte Pliniana attracted the interest of many visitors. Here some observations recorded in nearly 2000 years are reported. The measurements made during the XX century allowed also the evaluation of some hydraulic parameters of the spring system.

Keywords: Fonte Pliniana, ebb and flow, history, Como Lake.
\end{abstract}

Izvleček UDC 556.556(450.253)(091)

Arrigo A. Cigna: Pretok kraškega izvira Fonte Pliniana (Como, Italija): dve tisočletji podatkov

Izvir Fonte Pliniana je zbujal pozornost obiskovalcev že od rimskih časov dalje. Prispevek podaja nekaj opazovanj, zabeleženih v skoraj dveh tisočletjih. Meritve, opravljene v 20. stoletju, omogočajo oceno hidravličnih značilnosti tega izvira.

Ključne besede: Fonte Pliniana, intermitentni izvir, zgodovina, jezero Como, Italija.

\section{INTRODUCTION}

The Fonte Pliniana is an ebb and flow spring. Its period of flow occurs at rather irregular intervals. It is a typical karstic spring in Lias grey limestone very close to the border of Como Lake (Cigna \& Rondina, 1959) (Fig. 1). Some historical data on the spring are here reported as well as an evaluation of its main hydraulic parameters.

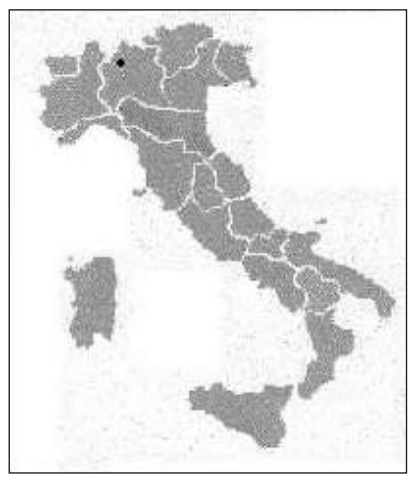

Fig. 1 - Location of the Fonte Pliniana, near Como

${ }^{1}$ Fraz. Tuffo, I-14023 Cocconato (Asti) Italy, E-mail: arrigocigna@tiscali.it 


\section{HISTORY}

The earliest reference to this spring apparently is in "Naturalis Historiae", a monumental work by Plinius the Elder (77 A.D.) published in the First Century A.D.: "in Comensi iuxta Larium lacum fons largus horis singulis semper intumescit et residit" [in the vicinity of Como, close to the lake Larium ${ }^{1}$, there is a large spring that every hour flows and ebbs].

Also his nephew, Plinius the Younger (96-109), describes the spring: "Fons oritur in monte, per saxa decurrit, excipitur cenatiuncula manu facta; ibi paulum retentus in Larium lacum decidit. Huius mira natura: ter in die statis auctibus ac diminutionibus crescit decrescitque." [= A spring issues in the mountain, flows through the rocks is kept in an small artificial room and shortly after reaches the lake Larium. It has a wonderful characteristic: every day its flow increases and decreases three times].

He supposed this effect to be due to the air, as it happens when a bottle is emptied, or to winds inside the mountain, which influence the water flow. Such quotations by both Plinies left their name to the spring and consequently to a near by building, Villa Pliniana, as it is called presently (Fig. 2). This villa was built in 1570 by Count Anguissola as a refuge to escape vengeance being involved in the murder of Duke Farnese.

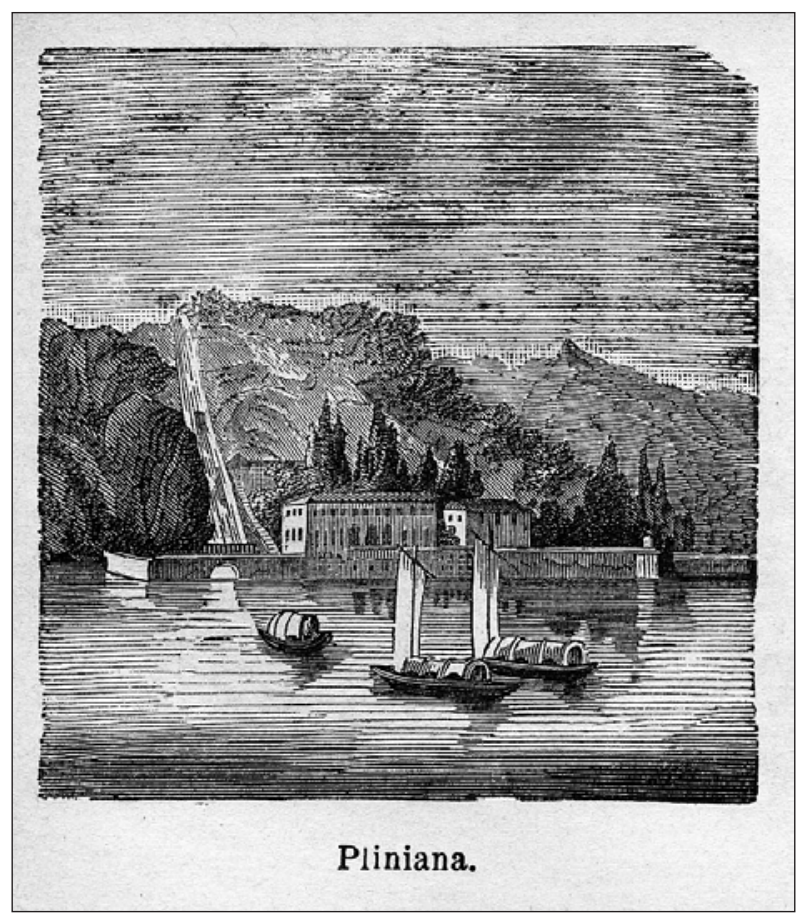

Fig. 2 - Villa Pliniana in a print of 1885 (Boniforti L., 1885)

${ }^{1}$ Larium is the Latin name of the Lake of Como, and it is still used presently.
Nearly 1500 years later another learned man, Leonardo da Vinci, in the first decade of the XVI century visited the region and was intrigued by the unusual behaviour of the spring. In Codex Leicester (Leonardo da Vinci, 15061513), a veritable treatise on water, he included few lines on the spring: "Come in molti lochi sitrova vene d'acqua che sei ore crescono e sei ore calano e io per me n'o veduta una in su lago di como ditta fonte pliniana la qual fa il predetto crescere e diminuire in modo che quando versa macina più mulina e quando manca cali si c'egli é come guardarsi lacqua in un profondo pozo" [= In many places there are streams of water which swell for six hours and ebb for six hours and I for my part have seen one above the lake of Como called Fonte Pliniana which increases and ebbs as I have said in such a way as to turn at a giddy speed; and when it fails it falls so low that it is like looking at water in a deep pit].

In Fig. 3 the passage by Leonardo excerpted from the Codex Leicester, leaf 11, v. is reproduced mirrored for an easier reading.

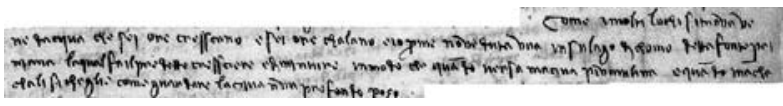

Fig. 3 - The passage by Leonardo on the Fonte Pliniana, excerpted from the Codex Leicester, leaf 11, v.

A couple of centuries later additional and more accurate measurements are available. In fact the owner of the Villa Pliniana reported to Ghezzi (1742) some news about the flow rate of the spring observed from June $11^{\text {th }}$ to July $2^{\text {nd }}, 1741$. Both the time interval between ebbs and the amount of the flow rate were not constant. A first series of data supplied by "a very kind gentleman" owner of Villa Pliniana are summarised as reported in Table 1. But Ghezzi was much intrigued by the behaviour of the spring and asked his friend to provide more accurate measurements. This gentleman measured the height of the water in the pool by means of a pole subdivided in Paris feet, inches and lines. The diagram referring to a couple of days is reported in Fig. 4 and 5. It was possible to identify the author of these data as Giuseppe Canarisi, since his family owned the Villa from 1676 to 1831 (Vasconi, 2007).

The average period of the ebbs was $99 \pm 21 \mathrm{~min}$ as measured in the month of June and $85 \pm 11 \mathrm{~min}$ in the month of July, but it may be assumed a rounded value of $1 \mathrm{~h} 30 \mathrm{~m}$. 
Table 1 - First series of the results obtained in the Villa Pliniana in 1741

\begin{tabular}{|l|c|c|c|}
\hline Date & Time interval & No. of ebbs & Period (min) \\
\hline June 11-12 & $22: 50$ & 14 & 96 \\
\hline June 14 & $5: 30$ & 6 & 55 \\
\hline June 15 & 24 & 12 & 120 \\
\hline June 16 & 24 & 16 & 90 \\
\hline June 17 & 24 & 13 & 108 \\
\hline & & Average $( \pm$ SD) & $99 \pm 21$ \\
\hline
\end{tabular}

In 1828 the Rev. Weever Walter, M.A., of St. John's, College, Cambridge, published a series of letters describing the places and the life after a travel. When in Como in his Letter XXVIII dated May 1827 a description of the lake and the Fonte Pliniana is reported: "...the intermittent fountain at Villa Pliniana: at the foot of the mountain, about 30 feet above the level of the lake, in a natural basin

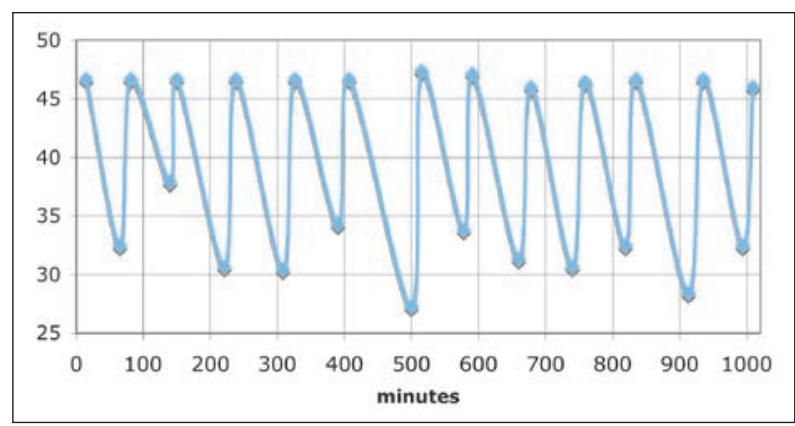

Fig. 4 - Flow and ebb of the Fonte Pliniana. The time scale starts at 9:05 of July 18, 1741. On the vertical axis the height of the water pool is reported.

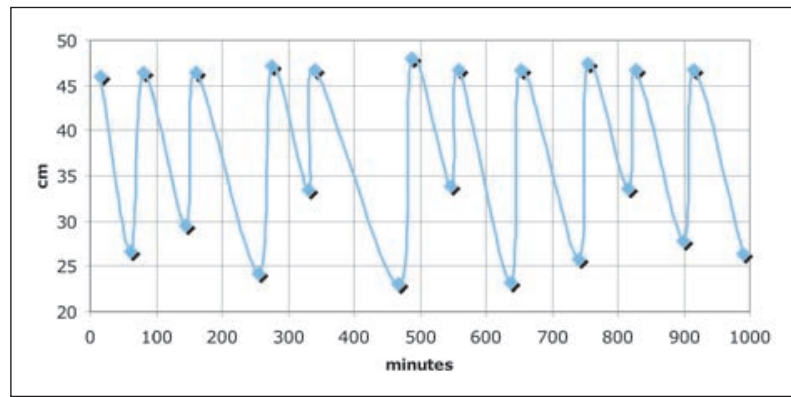

Fig. 5 - Flow and ebb of the Fonte Pliniana. The time scale starts at 12:49 of July 19, 1741. On the vertical axis the height of the water pool is reported. The interval between 341 and 468 minutes corresponds to the dinner time (19 to $21 \mathrm{~h}$ ), therefore during such an interval the measurement is missing.

hollowed out of the rock, having only a narrow outlet: a stream of water, beautifully clear, rushes out of the mountain and empties itself into this basin; for a certain length of time it flows so rapidly, that (the outlet being small) the basin fills up to the brim and even overflows its edges. Again the gush of water from the mountain gradually diminishes, and that in the basin as gradually acquires its lowest level. This alternation is repeated three times a day, though not with any great regularity." (Walter 1928)

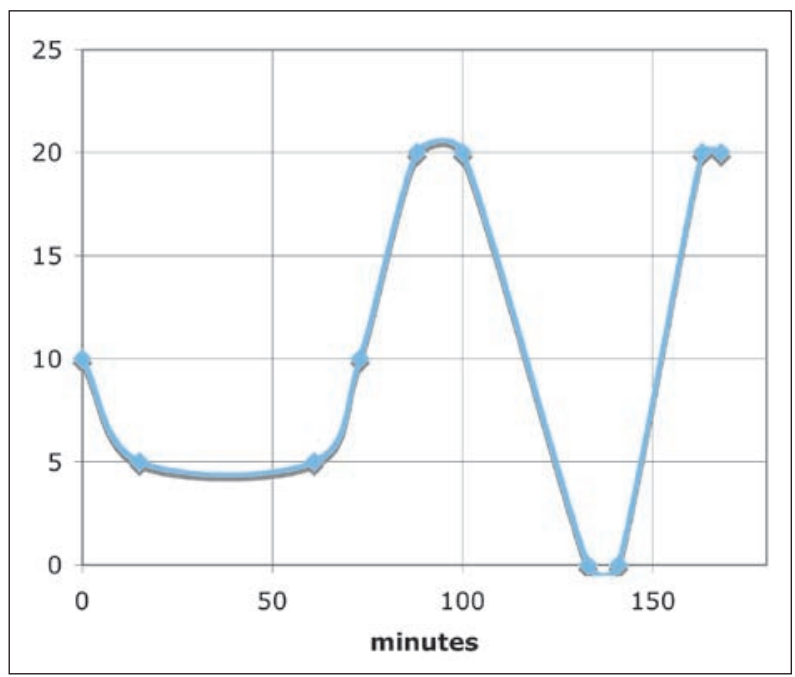

Fig. 6 - Flow and ebb of the Fonte Pliniana. The time scale starts at 13:02 of January 16, 1949.

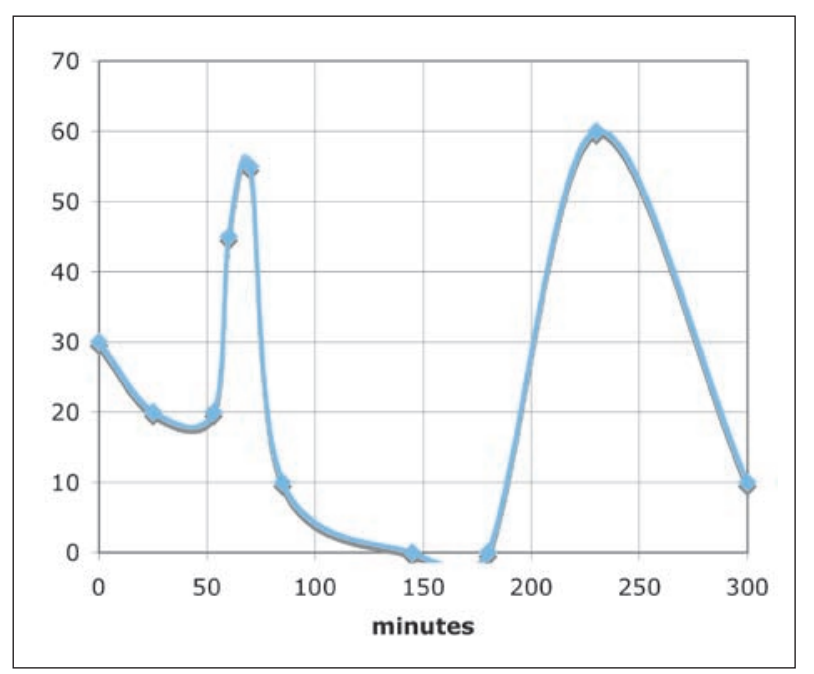

Fig. 7 - Flow and ebb of the Fonte Pliniana. The time scale starts at 9:50 of February 27, 1949

In modern time further observations were carried on in the years after the $2^{\text {nd }}$ World War when speleology developed again after such a difficult period. Carlo Mariani from the "Gruppo Grotte Desio" visited the Fonte Pliniana and in the months of January and February 1949 he made a series of measurements. On January 16, 1949 the average flow rate was around $3300 \mathrm{~L} /$ minute and the 


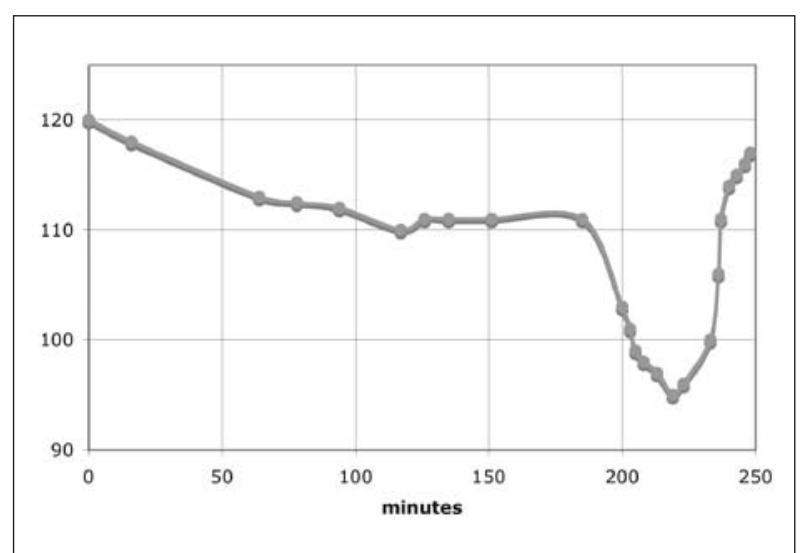

Fig. 8 - Flow and ebb of the Fonte Pliniana. The time scale starts at 11:28 of March 17, 1957 period was $76 \pm 13$ minutes; on February 27,1949 the average flow rate amounted to $1400 \mathrm{~L} /$ minute and the period increased to $160 \pm 13$ minutes; on both days the water temperature was $9.5^{\circ} \mathrm{C}$ (Mariani, 1949). In Fig. 6 and 7 such data are plotted.

Successively another series of measurements made on March 17, 1957, in the framework of a research on the springs in the province of Como (Cigna \& Rondina, 1959). The average flow rate was estimated around 6000 $\mathrm{L} /$ minute and the water temperature was $8.4^{\circ} \mathrm{C}$. In Fig. 8 the results of the measurements are reported.

It should be noted that the variation of water level observed in this last time, is of the order of tens of millimetres while in the past was of tens of centimetres. The difference is probably due to a change of the size of the outside water pool.

\section{QUANTITATIVE EVALUATION OF THE PHENOMENON}

Plinius the Young firstly advanced a hypothesis on the mechanism leading to the flow and ebb, as it was reported above. But a more realistic proposal was reported by Kircher (1668). This author did not referred directly to the case of the Fonte Pliniana, but he described faithfully its mechanism. Therefore the very original figure by Kircher may be used here.

In Fig. 9 some sources $G$ feed water to the ponds $\mathrm{F}$; then water reaches the point $\mathrm{E}$ in a cave in the mountain. A siphon B-A-I is the outlet of the reservoir inside the cave. When the waterfall $\mathrm{D}$ fills the void to a level higher than the top of the siphon (A) it discharges the water outside until the level inside the cave is lower than the inlet of the siphon (B) and the flow is stopped. In the case here described I is the Fonte Pliniana and $\mathrm{L}$ is the Lake of Como. But how a siphon works in nature will be discussed later. The periods of the flow and ebb as observed since Pliny's time to present are summarised in Table 2. In antiquity time was divided to have 12 hours during the day and 12 hours during the night and since it is not known the date of the observations made by the Plinies and Leonardo, the periods corresponding to their observations are reported with an approximation of $30 \%$, corresponding to the maximum difference of length of the hours between solstice and equinox at the latitude of Como Lake. Such periods span between 60 and 720 minutes and also the flow rate is rather irregular.

Mangin (1973) and Bonacci \& Bojanic (1991) described the modelling of non-constant karst springs. Both papers reported rather accurate evaluations of the whole system thanks to a large number of data of the flow rate in function of time. Unfortunately this is not the case considered here, where the records spread over two thousands years but the accuracy of the measurements is somewhat uncertain.

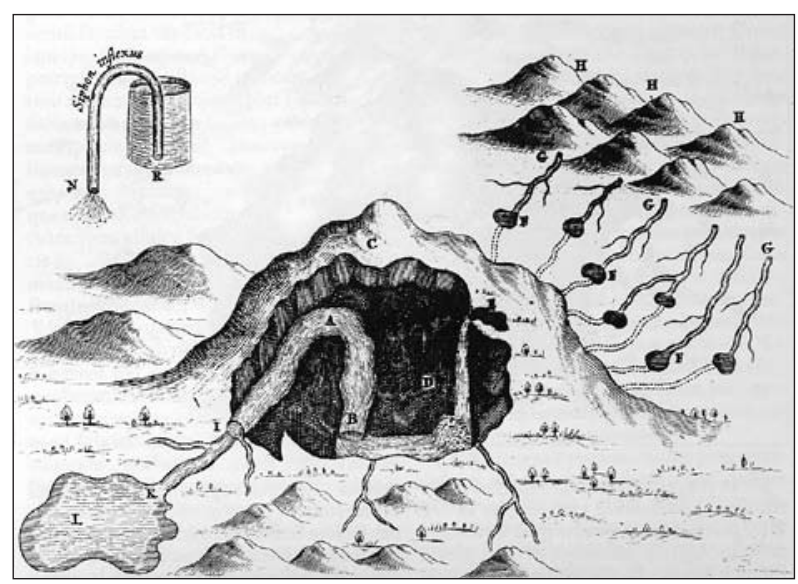

Fig. 9 - The hydraulic system of a flow and ebb spring. From Kircher (1668, p. 306)

Anyway it is possible to carry on some tentative evaluation of the factors involved in the hydraulic system of the Fonte Pliniana. 
Table 2 - Periods of the Fonte Pliniana

\begin{tabular}{|l|c|c|}
\hline Reference & Year & Period (minutes) \\
\hline Plinius the Elder, 77 & 77 & $60 \pm 19$ \\
\hline Plinius the Young, 96-109 & $96-109$ & $240 \pm 74$ \\
\hline Leonardo da Vinci, 1506-13 & $\sim 1510$ & $720 \pm 220$ \\
\hline Ghezzi, 1742 & 1741 & 90 \\
\hline Walter, 1828 & 1827 & 240 \\
\hline Mariani, 1949 & 1949 & 76 to 160 \\
\hline Cigna \& Rondina, 1959 & 1957 & $>210$ \\
\hline
\end{tabular}

Let $\mathrm{V}$ be the volume of the void between $\mathrm{B}$ and $\mathrm{A}, \mathrm{Q}_{\text {in }}$ the inflow from $E$ and $Q_{\text {out }}$ the outflow from $I$. In addition let $\mathrm{q}$ be a fraction of $\mathrm{Q}_{\text {out }}$ which flows at the minimum of the period. Then the following equations can be written:

$$
\begin{aligned}
& \mathrm{q}=\varepsilon \mathrm{Q}_{\text {out }} \quad \text { with } 0<\varepsilon<1 \\
& \mathrm{~V}=\left(\mathrm{Q}_{\text {out }}-\mathrm{Q}_{\text {in }}\right) \mathrm{T}_{\text {ou }}
\end{aligned}
$$

Then the volume V may be calculated:

$$
\begin{aligned}
& \mathrm{V}=\left(\mathrm{Qi}_{\mathrm{n}}-\mathrm{q}\right) \mathrm{T}_{\text {in }} \\
& \mathrm{V}=\left(\mathrm{Q}_{\text {out }}+\mathrm{q}-\mathrm{Q}_{\text {in }}\right) \mathrm{Ti}_{\mathrm{n}}
\end{aligned}
$$

Finally also $\mathrm{Q}_{\text {in }}$ can be calculated

$$
\mathrm{Q}_{\text {in }}=\mathrm{Q}_{\text {out }} \frac{(1+\varepsilon) \mathrm{T}_{\text {out }}+\varepsilon \mathrm{T}_{\text {in }}}{\mathrm{T}_{\text {out }}+\mathrm{T}_{\text {in }}}
$$

By substituting the results of the measurements made in the last century and by assuming that $\varepsilon$ is small enough to be neglected, a rough evaluation of the inflow and the volume of the reservoir inside the mountain is obtained and reported in Table 3.

The mean yearly rainfall in the region is around $1000 \mathrm{~mm} /$ year. By assuming an average value for $\mathrm{Q}_{\text {out }}$ of $3000 \mathrm{~L} / \mathrm{min}$ the annual flow is around 1.5-2 million of $\mathrm{m}^{3}$. With a runoff around $50 \%$ and a rainfall as reported above, a basin of about some $\mathrm{km}^{2}$ would supply enough water to the spring. Since the average annual temperature of the mountains above the spring is of $7^{\circ} \mathrm{C}$ and the difference of altitude is nearly $1000 \mathrm{~m}$, a gradient of $0.234^{\circ} \mathrm{C}$ for $100 \mathrm{~m}$ of fall due to the transformation of work into heat would increase the water temperature of the basin from 7 to a final value of $9.3^{\circ} \mathrm{C}$, very close to the $9.7^{\circ} \mathrm{C}$ measured with a calibrated thermometer (Cigna \& Rondina, 1959). This result supports the connection between a recharge basin in the mountains above the spring with the spring itself.

But in nature it is necessary to eliminate the air in the upper part in order to prime the siphon. When the water level in the reservoir $\mathrm{V}$ rises above the upper part of the siphon the water will start to flow in the descending branch with a simple overflow above the edge. But if the water entering the reservoir will reach a level high enough, such an overflow will increase to a point of dragging the air in the descending branch.

Due to the irregular shape of the conduit and the irregularities of the inflow the drag of the whole air will not take place always at the same conditions. If the water reaches a level in the reservoir higher than usually before the siphon is triggered, the outflow of the spring will be occasionally more relevant, as it has been recorded, e.g., by Ghezzi (1742).

Table 3 - Hydraulic parameters of the Fonte Pliniana

\begin{tabular}{|l|c|c|c|c|c|}
\hline Reference & $\begin{array}{c}T_{\text {out }} \\
\text { minutes }\end{array}$ & $\begin{array}{c}T_{\text {in }} \\
\text { minutes }\end{array}$ & $\begin{array}{c}Q_{\text {out }} \\
L / \text { minutes }\end{array}$ & $\begin{array}{c}Q_{\text {in }} \\
L / \text { minutes } \\
\text { (calculated) }\end{array}$ & $\begin{array}{c}V \\
m^{3} \\
\text { (calculated) }\end{array}$ \\
\hline Mariani, Jan.16,1949 & 43 & 44 & 3300 & 1600 & 150 \\
\hline Mariani, Feb.27,1949 & 92 & 40 & 1400 & 1000 & 60 \\
\hline Mariani, Feb.27,1949 & 70 & 50 & 1400 & 800 & 70 \\
\hline Cigna \& Rondina, Mar. 17, 1959 & 219 & 29 & 6000 & 5000 & 170 \\
\hline
\end{tabular}




\section{CONCLUSIONS}

The spring was known since the first observations for its irregular behaviour both of the flow rate and the period. The flow rate is strongly affected by the amount of rain and snow melting in the basin above the spring. The flow and ebb is due to the existence of a siphon at the outlet of a reservoir. But this simplified model accounts only for the flow and ebb, since the real feature of the hydraulic system could be complicated, e.g., by existence of more reservoirs connected each other directly or through siphons.

Such a hypothesis is supported by the irregular flow rate reported in Fig. 7, which was detected by rather fre- quent measurements of the water level in the outside basin. The data recorded in previous investigations aimed to establish the maximum and minimum levels only, and therefore it was not possible to study the details of the flow rate. In addition such a complex network could also be modified during the centuries by erosion and filling of passages by both rock and organic debris.

In order to understand fully the mechanisms involved in this historic spring it would be desirable to carry out a systematic monitoring of its water flow by means of modern automatic devices, which provide a detailed and extended record rather easily.

\section{ACKNOWLEDGEMENTS}

The author is very grateful to dr. Saba Dell'Oca and the Vice-Mayor of Torno, prof. Marcella Vasconi who kindly provided the information on the owner of Villa Pliniana at the time of the measurements reported by N. Ghezzi. The extremely fruitful discussion with prof. G. Badino clarified many issues and improved greatly the whole paper. The relevant suggestions provided by $d r$. O.Bonacci and dr. A.Kranjc, and the copy of some references transmitted by dr. F.Gabrovsek are also gratefully acknowledged.

\section{REFERENCES}

Bonacci O. \& D. Bojanic, 1991: Rhythmic karst springs. Hydrol. Sci. J. 36,1-2: 35-47, Wallingford, Oxfordshire

Boniforti L., 1885: Per Laghi e Monti. Premiata Guida descrittiva, storica, artistica, pratica.

Dumolard -Roux, Milano-Torino.

Cigna A. \& G. Rondina, 1959: Sull'idrologia carsica epigea nel territorio della provincia di Como (Lombardia). Atti Soc. It. Sc. Nat., 98,1, 84-120, Milano

Ghezzi N., 1742: Dell'origine delle fontane. Presso Simone Occhi, 273-275, Venezia

Kircher A., 1668: Mundus Subterraneus in XII libros digestus. J. Janssonium à Waesberge \& Filios, 190-192, Amstelodami.
Leonardo da Vinci, 1506-13: Codex Leicester, leaf 11, v. Mangin A., 1973: Sur les transferts d'eau au niveau du karst noyé a partir de travaux sur la source de Fontestorbes. Ann. Spéléologie, 28, 1, 21-40

Mariani C, 1949: Pliniana. Gruppo Grotte Desio, Manuscript unpublished.

Plinius C. S., 77: Naturalis Historia. Book. 2, cap. XCV. Giardini, 1984, Como.

Plinius G.C.S., 96-109: Liber IV, Epistula 30

Vasconi M., 2007: Personal communication by the ViceMayor of the Community of Torno.

Walter W., 1828: Letters from the continent. W. Blackwood Edinburgh \& T. Cadell, Strand: 203-206, London. 